\title{
INISIASI PEMASARAN DARING DI KELOMPOK USAHA MELUR DI DESA SAMBIREJO, KECAMATAN PERCUT SEI TUAN
}

\author{
Khairunnisa Harahap ${ }^{1}$, Izwar Lubis ${ }^{2}$, Tri Effiyanti ${ }^{3 *}$ \\ ${ }^{1}$ Program Studi Akuntansi, Fakultas Ekonomi, Universitas Negeri Medan, \\ ${ }^{2}$ Program Studi Pendidikan Teknik Mesin, Fakultas Teknik, Universitas Negeri Medan \\ ${ }^{3}$ Program Studi Pendidikan Ekonomi, Universitas Negeri Medan \\ Jl. Willem Iskandar pasar V-Kotak Pos No. 1589 - Medan 20221 \\ Penulis Korespodensi: trieffiyanti@yahoo.com
}

\begin{abstract}
Abstrak
Kelompok Usaha Melur yang merupakan Mitra kegiatan pengabdian ini memiliki beberapa permasalahan tata kelola manajerial, yaitu: 1) Belum terorganisasinya pembukuan dengan baik. 2) pemasaran produk masih sangat sederhana dan belum memanfaatkan teknologi informasi. 3) Kurangnya alat mesin jahit untuk menambah produksi. Tujuan kegiatan pengabdian masyarakat ini adalah untuk meningkatkan kapasitas manajerial dan pemasaran pada Kelompok Usaha Melur di Desa Sambirejo, Percut Sei Tuan. Tujuan tersebut dicapai melalui pendampingan kepada Kelompok Usaha Melur di bidang pembukuan/pengelolaan keuangan dan strategi marketing berbasis internet. Kelompok Usaha rumah tangga ini bergerak dalam bidang pembuatan keset kaki. Bahan baku produk tersebut menggunakan limbah kain/produksi penjahit lain. Pembuatan keset kaki ini juga memberdayakan ibuibu rumah tangga di daerah sekitar yang ingin menambah pengetahuan jahit menjahit dan pada gilirannya menambah penghasilan ibu-ibu anggota kelompok usaha tersebut. Pelatihan pembukuan dilakukan dengan memberikan pemahaman dan pendampingan terkait pencatatan kas masuk dan keluar, penghitungan harga pokok produksi dan pembuatan laporan keuangan. Selanjutnya, pendampingan pemasaran berbasis internet dilakukan dengan memberikan wawasan untuk memaksimalkan teknologi yang ada untuk memasarkan produk mereka. Metode yang dipakai dalam pengabdian ini adalah dengan menggunakan penyuluhan dan pendampingan hingga kelompok usaha melur memiliki pembukuan yang rapih dan memiliki toko online di media sosial.
\end{abstract}

Kata kunci: Pendampingan, Pengelolaan Keuangan, Pemasaran Online, UKM Melur.

\begin{abstract}
"Melur Entrepreneur Community" have several gavernance problem, such as: 1) the absence of bookkeeping systems. 2) traditional marketing strategy, and 3) ineffectiveness of production. This community service activity conducted in Melur Entrepreneur Community aims to overcome the problems as mentioned. That purpose was achieved through training and guiding the member of Melur Entrepreneur Community in bookeeping dan marketing strategy based on Information Technology. Melur Entrepreneur Community are focus in making doormats from the waste of tailor production. They also empowering woman of households who want to gain a knowledge of sewing and in turn would increase their income. Bookkeeping training is done by providing insight and assistance related to the recording of incoming and outgoing cash, cost analysis of production and financial reporting. Furthermore, knowledge of internet based marketing is delivered by providing insight to maximize existing technology to marketing their products. The method which used in this activity is counseling and training to achieve the outcome, that is the availability of bookkeeping and online store on social media.
\end{abstract}

Keywords: training/guiding, financial administration, online marketing, SMEs.

\section{Pendahuluan}

Sejak tahun 1979 Badan Kependudukan dan Keluarga Berencana Nasiomal (BKKBN) telah melaksanakan kegiatan Usaha Peningkatan Pendapatan Keluarga Sejahtera (UPPKS). UPPKS adalah sebuah program yang berfungsi menggerakkan roda ekonomi keluarga melalui pembelajaran usaha ekonomi dengan cara menggugah minat dan semangat keluarga untuk berwirausaha dengan harapan terdapatnya perubahan perilaku keluarga, yakni keluarga yang mau, tahu dan mampu melakukan usaha ekonomi produktif atau perilaku ekonomi produktif yang efektif. Salah satu programnya adalah Pengembangan pengetahuan dan keterampilan kewirausahaan melalui pelatihan teknis dan manajemen usaha khususnya terhadap keluarga pra sejahtera yang terhubung dalam kelompok UKM.

Lembaga Pengabdian Masyarakat UNIMED bersama dengan BKKBN telah bekerjasama 
melakukan pembinaan dan pendampingan UPPKS untuk melaksanakan salah satu Tri Dharma Perguruan Tinggi. Salah satu Kelompok Usaha yang menjadi mitra LPM Unimed dalam Kegiatan UPPKS adalah Kelompok Usaha Melur. Usaha industri rumahan yang terletak di Desa Sambirejo Kecamatan Percut Sei Tuan ini di kelola oleh Ibu Suprianti menjalankan usaha pembuatan keset kaki sejak tahun 2005, dengan memberdayakan ibu-ibu rumah tangga dan remaja wanita putus sekolah. Usaha ini merupakan industro rumahan (Home Industry) yang sudah memiliki pangsa pasar di seluruh daerah di Sumatera Utara dan beberapa provinsi lain di Indonesia seperti: Nusa Tenggara Timur, Kudus, Bangka Belitung, dan DKI Jakarta. Hal ini membuktikan bahwa keset kaki yang dihasilkan sangat diminati oleh berbagai kalangan masyarakat luas.

Dalam upaya pemasarannya, usaha ini telah mengikuti berbagai macam pameran yang diselenggarakan baik di tingkat regional maupun di tingkat nasional. Sistem pemasaran yang dilakukan tidak langsung ke konsumen melainkan di pasarkan ke agen-agen atau reseller setelah itu baru dipasarkan ke konsumen. Usaha ini menerima pesanan dari agen atau reseller dan setelah pesanan itu datang barulah kegiatan produksi dilakukan. Usaha industri keset kaki yang ditekuni Ibu Suprianti masih menggunakan manajemen usaha sederhana yang berlandaskan azas kekeluargaan dan belum mengadopsi sistem manajemen modern. Disamping itu, kelompok usaha ini belum melakukan pencatatan keuangan sebagaimana mestinya, padahal pembukuan adalah bahan acuan dalam pengambilan keputusan. Oleh karena hal tersebut pula kelompok usaha ini sulit mendapatkan tambahan modal dari pihak perbankan meskipun telah beberapa kali mencoba mengajukan pinjaman kredit.

Eksistensi usaha industri rumah tangga memang tidak dapat diragukan lagi karena terbukti mampu bertahan dan menjadi roda penggerak ekonomi keluarga. Disisi lain, usaha industri rumah tangga juga menghadapi berbagai permasalahan, yaitu terbatasnya modal kerja, Sumber Daya Manusia yang rendah, dan minimnya penguasaan ilmu pengetahuan serta teknologi (KUMKM dan BPS, 2004). Keadaan tersebut mengakibatkan stagnansi dalam pertumbuhan UMKM. Indarti (2010) mengungkap salah satu penyebab berbagai kendala tersebut adalah knowledge stickiness. Berbagai keterbatasan yang dimiliki pelaku UKM terjadi karena ia berpegang hanya pada pengetahuan awal/internal yang dimilikinya. Sementara untuk memiliki keunggulan kompetitif, pelaku bisnis harus terus melakukan improvisasi dan penambahan pengetahuan secara berkelanjutan pada produk dan aspek manajerial serta operasionalnya (Indarti, 2010). Selanjutnya, arus globalisasi dan persaingan membuat usaha rumahan harus mampu menghadapi tantangan global, seperti meningkatkan inovasi produk dan jasa, pengembangan sumber daya manusia dan teknologi, serta perluasan area pemasaran. Peningkatan tersebut adalah kunci dari keunggulan kompetitif yang seharusnya dimiliki oleh UMKM.
Mengacu pada keadaan tersebut maka kegiatan pengabdian masyarakat ini menargetkan pada perbaikan aspek-aspek yang teridentifikasi sebagai masalah pada mitra dan aspek tersebut dianggap penting untuk meningkatkan keunggulan kompetitif mitra. Solusi yang dilakukan dalam pelaksanaan yang kegiatan pengabdian masyarakat ini adalah dengan menggunakan media pelatihan/penyuluhan dan pendampingan. Kegiatan Pelatihan/Penyuluhan bertujuan untuk meningkatkan kemampuan dan ketrampilan masyarakat pengrajin keset kaki pada beberapa aspek pemasaran dan pembukuan. Pelatihan tersebut juga bertujuan untuk membentuk kesadaran pengrajin mengenai pentingnya pembukuan yang rapi serta pemasaran yang inovatif sehingga dapat memperoleh modal kerja dan bertambah luasnya daerah pemasaran, dan pada gilirannya bebagai perbaikan yang terjadi perlahan akan meningkatkan pendapatan sebagai mana yang telah dialami pada kegiatan-kegiatan pengabdian (IbM) sebelumnya (Irawan dkk., 2016; Sulila, 2016; Afifah dan Suryani, 2016).

Untuk mencapai tujuan pelatihan tersebut, maka rancangan pelatihan/penyuluhan yang dilakukan dengan cara sebagai berikut:

a. Pelatihan/Penyuluhan di bidang pembukuan adalah Pelatihan Pencatatan penerimaan dan pengeluaran ke dalam buku besar, melakukan pencatatan ke dalam jurnal khusus, dan melakukan Perhitungan Harga Pokok Produksi. Pendampingan ini bertujuan untuk memberikan bimbingan dalam proses pembukuan.

b. Pelatihan/penyuluhan di bidang pemasaran adalah Pelatihan Pengemasan Produk Keset kaki dengan memberi logo dan Pelatihan Penggunaan media sosial dalam Pemasaran Online.

Produk utama dalam kegiatan pengabdian masyarakat ini adalah menghasilkan laporan keuangan sederhana bagi usaha kerajinan keset dan website pemasaran online. Keberadaan kedua fitur tersebut dalam kelompok usaha ini diharapkan mampu mendorong efikasi diri kelompok usaha melur maupun ibu-ibu rumah tangga sebagai anggota untuk secara berkelanjutan mampu mengambil keputusan strategis untuk mengembangkan usaha (Handaru, dkk., 2015)

\section{Laporan Keuangan Sederhana bagi UKM}

Dalam program pengabdian ini, diharapkan dapat membekali pengetahuan dan ketrampilan pengrajin keset kaki mengenai pembukuan atau laporan keuangan sederhana. Para pengrajin diharapkan mampu membuat pencatan yang rapi mengenai penerimaan dan pengeluaran dalam usaha, mencatat jumlah penjualan ke dalam jurnal khusus dan mencatat perhitungan laporan harga pokok produksi.

\section{Pemasaran Online}

Dalam program pengabdian ini diharapkan dapat mengatasi persoalan pemasaran yang selama ini menjadi kendala UKM dalam memasarkan produknya. Selain media promosi diperluas, Program ini didesain 
untuk membuat media promosi produk secara online yaitu dengan melatih seluruh anggota kelompok usaha Melur melakukan pemasaran produk keset kaki di media sosial seperti: Facebook, Blackberry Massanger, Whatsapp dan Instagram.

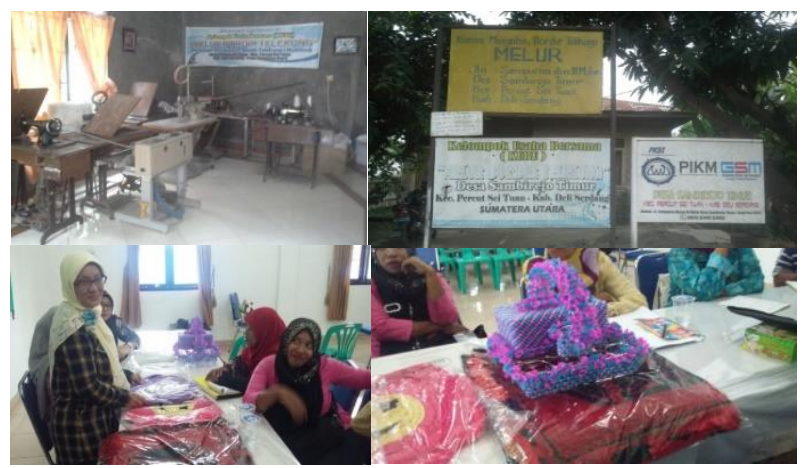

\section{Gambar 1. Suasana Kelompok Usaha Melur dan Produknya}

\section{Metode Pelaksanaan}

Langkah-langkah yang dilakukan untuk mencapai tujuan dan sasaran kegiatan ini adalah pelatihan pengelolaan keuangan dengan diskusi dan simulasi dan dilakukan pendampingan dalam pembuatan laporan keuangan. Selanjutnya memberikan pengarahan dan pemahaman betapa pentingnya promosi produk dengan menggunakan media sosial. Lalu melakukan pelatihan dan pendampingan dalam pemasaran dengan pelatihan memakai sosial media sebagai bentuk untuk promosi produk. Kegiatan promosi di lanjutkan dengan pengunggahan produk ke beberapa media sosial. Untuk itu dilakukan kerjasama yang baik antara dosen pelaksana dengan pelaku usaha serta dalam mendukung pelaksanaan program ini maka akan bekerjasama dengan desainer dalam membantu pembuatan logo dalam pelatihan program sehingga kegiatan usaha unit usaha mendapatkan laba pada tingkat yang diharapkan.

Pihak yang terlibat dalam kegiatan ini adalah Ketua Tim Pengabdian Masyarakat, kedua Anggota Tim, dan Dua orang Tenaga Lapangan. Tim ini bertugas dalam penyelenggaraan Pelatihan Pembukuan dan Pemasaran Online di Atas. Ketua Tim dan kedua anggotanya bertugas sebagai perancang konsep kegiatan dan narasumber dalam kegiatan pelatihan tersebut. Sementara tenaga lapangan bertugas menyiapkan berbagai keperluan teknis untuk keberlangsungan pelatihan pembukuan dan pelatihan pemasaran online yang akan diselenggarakan.

Selanjutnya, pihak yang terlibat tentunya adalah peserta, yang terdiri dari ketua dan anggota Kelompok Usaha Melur. Peserta adalah objek pengabdian yang akan menerima transfer pengetahuan dari narasumber. Sebelumnya peserta telah dimintai kesediaannya dengan harapan peserta akan siap menerima materi yang akan disampaikan. Peserta dilatih dan didampingi untuk mampu membuat pembukuan sederhana dari aktivitas bisni yang dijalankannya. Selanjutnya peserta dirangsang untuk menyadari pentingnya strategi pemasaran, dan tersedianya strategi pemasaran yang murah dan mudah namun dapat menjangkau wilayah yang luas, yaitu pemasaran berbasis media sosial. Dan, peserta dilatih dan didampingi untuk mampu melakukan strategi pemasaran dengan bantuan media sosial. Peran peserta dalam program Pengabdian Masyarakat ini, antara lain:

1) Memberikan informasi data-data kondisi usaha kecil dan system operasionalnya.

2) Memberi masukan tentang harapan dan target usaha.

3) Mendukung pelaksanaan pelatihan manajemen dan pembukuan serta pemasaran.

4) Mempelajari tentang alur pembukuan keuangan.

5) Mempelajari mix marketing usaha, dan memiliki akun berbagai media social dalam promosi usaha.

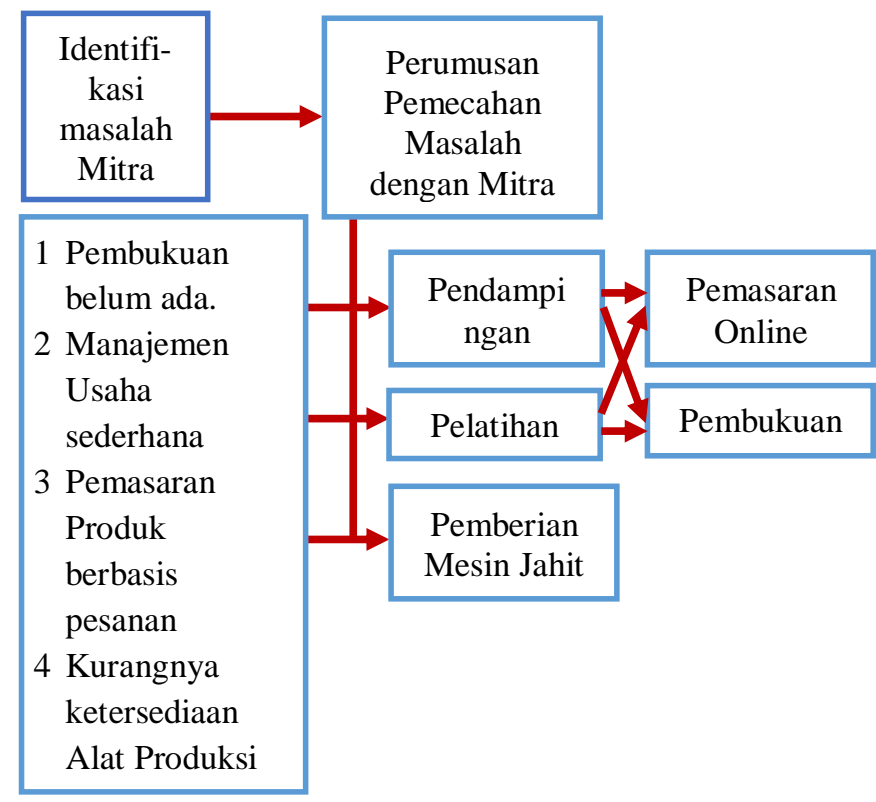

Gambar 2. Alur Pelaksanaan Program

\section{Hasil dan Pembahasan}

Pelaksanaan kegiatan diawali dengan FGD persiapan awal yang melibatkan semua anggota tim dan tenaga lapangan. Hal ini berguna untuk merumuskan konsep dan teknis kegiatan, sehingga pada pelaksanaan kegiatan pelatihan pembukuan dan pemasaran online nantinya berjalan dengan efisien dan minim kendala. Pelaksanaan FGD persiapan dilakukan pada tanggal 28 September 2016. FGD ini beralan dengan baik dan seluruh anggota tim mampu menyamakan persepsi dan dapat diambil langkah strategis untuk pelaksanaan pelatihan.

Pada tanggal 15 Oktober 2016 dilaksanakan kegiatan pelatihan pembukuan. Pelatihan dilakukan di rumah Ibu Suprianti selaku ketua kelompok usaha melur. Pelatihan dihadiri seluruh anggota kelompoknya. Kondisi peserta memang menunjukkan bahwa mereka belum sadar akan pentingnya pembukuan dalam kegiatan usaha, sehingga membutuhkan waktu yang cukup lama untuk membuat mereka memahami pentingnya pembukuan. Diskusi berjalan cukup panjang dan hangat. Materi pembukuan 
disampaikan oleh ketua tim, ibu Khairunnisa Harahap. Pelatihan berjalan lancer sesuai dengan harapan. Pemahaman mengenai pembukuan tentunya belum secara penuh dipahami oleh peserta pada tahap ini, Sehingga peserta diberi tanggung jawab untuk menyelesaikan pembukuannya selama tiga bulan terakhir dalam satu minggu kedepan. Pelatihan pembukuan dan pemasaran online sengaja diberi jarak satu minggu untuk memberikan waktu bagi para peserta dalam membuat pembukuannya sendiri dan lantas di pertemuan berikutnya peserta sudah lebih siap menerima materi pemasaran online.

Satu Minggu kemudian, tanggal 22 Oktober 2016, tim melanjutkan kegiatan dengan pelatihan pemasaran online. Sebelumnya, tim mengevaluasi hasil kerja peserta dengan tugas pembukuan yang telah diberikan. Setelahnya, tim memulai pelatihan pemasaran online dengan terlebih dahulu menyampaikan keutamaan strategi pemasaran bagi UMKM, dan bagaimana memaksimalkan Sosial Media untuk memasarkan produk UMKM. Materi tersebut disampaikan oleh anggota tim, yaitu Bapak Gaffar Hafiz Sagala. Kemudian setelah menyampaikan keutamaannya maka peserta dilatih dan didampingi untuk membuat laman sosial media untuk aktivitas bisnisnya dan melakukan langkah-langkah strategis pada laman sosial media tersebut dalam upaya memaksimalkan penjualan produk peserta pelatihan. Pelatihan tersebut dilakukan oleh anggota tim lainnya, yaiti bapak Izwar Lubis.

Selama proses pelatihan berlangsung tim melakukan evaluasi secara berkelanjutan. Evaluasi dilakukan pada saat sebelum, selama dan setelah pelaksanaan kegiatan. Dengan menggunakan pendekatan community development officer/CDO. Pelatihan dalam pembukuan keuangan dievaluasi dengan penugasan dalam menyiapkan laporan keuangan usahanya. Pelatihan pemasaran dilakukan dengan pengelolaan website sebagai sarana dalam melakukan proses promosi.

Indikator tercapainya tujuan pengabdian ini adalah, telah di buatnya catatan transaksi usaha pada beberapa bulan sebelumnya (tergantung dari catatan transaksi yang tersedia) yang di catat dengan rapi dan benar ke dalam buku besar kas masuk dan keluar, buku pembelian dan penjualan serta laporan keuangan. Sementara itu, indicator tercapainya pelatihan pemasaran online adalah dengan tersedianya laman media sosial UMKM yang dijalankan peserta, dan pahamnya peserta mengenai apa yang harus dilakukannya dengan laman tersebut untuk memaksimalkan penjualan. Hasil dari pelaksanaan kegiatan ini, akan menjadi masukan untuk keberlanjutan pengabdian di tahun yang akan datang.

Setelah dilaksanakan Pelatihan Pembukuan dan Pemasaran Online, maka tampak dampak kegiatan tersebut yang ditunjukkan oleh peserta pelatihan. Luaran dan dampak tersebut dapat ditinjaupada tabel di bawah ini.

\section{Tabel 1. Luaran dari Setiap Solusi}

\begin{tabular}{|c|c|}
\hline Solusi & Luaran \\
\hline $\begin{array}{l}\text { 1) Pemberian pelatihan } \\
\text { teoritis dan teknis } \\
\text { mengenai pembukuan } \\
\text { sederhana untuk kas } \\
\text { masuk dan keluar } \\
\text { 2) Simulasi dan latihan } \\
\text { penyusunan } \\
\text { pembukuan sederhana } \\
\text { 3) Penghitungan Harga } \\
\text { Pokok Produksi } \\
\text { 4) Pembuatan Laporan } \\
\text { Keuangan }\end{array}$ & $\begin{array}{l}\text { - Perangkat pembukuan } \\
\text { usaha individu: } \\
\text { formulir/jurnal kas } \\
\text { masuk, formulir/jurnal } \\
\text { kas keluar, dan buku } \\
\text { laporan kas . } \\
\text { - Buku Besar/ Jurnal } \\
\text { Khusus Pembelian dan } \\
\text { Penjualan } \\
\text { - Laporan Harga Pokok } \\
\text { Produksi } \\
\text { - Laporan Keuangan }\end{array}$ \\
\hline $\begin{array}{l}\text { 5) Pendampingan dalam } \\
\text { pemutakhiran saluran } \\
\text { pemasaran berbasis } \\
\text { teknologi informasi } \\
\text { yang } \quad \text { disesuaikan } \\
\text { dengan preferensi } \\
\text { mitra. }\end{array}$ & $\begin{array}{l}\text { - Penggunggahan } \\
\text { dokumentasi produk dan } \\
\text { profil usaha ke website } \\
\text { pemasaran online: } \\
\text { www.tokopedia.com. } \\
\frac{\text { www.olx.co.id, }}{\text { www.bukalapak.com }} \text { dan } \\
\text { - Pemasaran produk di } \\
\text { Sosial Media (BBM, } \\
\text { WA, Instagram dan FB) }\end{array}$ \\
\hline
\end{tabular}

\section{Kesimpulan}

Dari aktivitas yang dilakukan tim pelaksana pengabdian masyarakat pada Kelompok Usaha Melur, terdapat aspek-aspek strategis yang dapat ditingkatkan disamping pembukuan. Selanjutnya Tim pelaksana menyadari adanya hambatan dalam diri peserta dalam menggunakan teknologi informasi. Hal ini disebut dengan "Computer Anxiety". Sehingga dari temuan ini maka:

1. Pada kegiatan pengabdian selanjutnya, perlu dilakukan pendampingan mengenai diversivikasi dan diferensiasi produk pada kelompok usaha melur. Kelompok ini telah memiliki produk yang menarik, hanya saya mereka tidak memiliki jenjang kualitas dari produknya. Sehingga diperlukan diversifikasi. Selanjutnya kelompok usaha ini masih memiliki hanya dua produk unggulan, yakni keset kaki dan mukena. Sehingga perlu dilakukan diferensiasi produk. Baik dari desain keset dan mukenahnya, maupun merambah ke produk lainnya. Disamping itu, UMKM ini juga mulai merintis usaha kripik tradisional. Kualitas rasa yang dimiliki cukup baik. Hanya saja kelompok ini masih awam dengan inovasi packaging, branding, dan inovasi rasa. Sehingga pendampingan mengenai aspek-aspek tersebut perlu dilakukan pada kegiatan pengabdian berikutnya.

2. Internalisasi pemasaran online pada peserta kelompok melur memang berjalan baik. Tetapi ditemuan terdapat kekakuan para anggota dalam menggunakan teknologi informasi. Mereka tidak terbiasa berinteraksi dengan computer ataupun smartphone. Sehingga membuka 
peluang untuk reseller yang lebih mapan teknologi informasi dapat menjadi solusi yang tepat. Pemberdayaan mahasiswa dalam kegiatan serupa (misalnya: MK Kewirausahaan, MK Pemasaran, PKM-Kewirausahaan, dsb) dapat mendorong penjualan UMKM. Melibatkan pihak ketiga bisa menjadi alternative solusi dan mencapai tujuan bersama. Sehingga pihak UMKM dapat focus memaksimalkan kualitas produk. Pihak ketiga yang dianggap lebih mapan IT dapat focus melakukan strategi pemasaran online. Keuntungan keduanya dapat dirumuskan dengan skema bagi hasil tertentu sesuai kesepakatan bersama.

\section{Rekomendasi}

Pembukuan dan pemasaran online e adalah hal umum bagi kegiatan bisnis terutama UMKM. Akan tetapi kesadaran UMKM yang tertinggal dari inovasi tenologi akan kedua aspek tersebut menghasilkan opportunity cost tersendiri. Sayangnya, keadaan tersebut belum banyak disadari oleh pelaku UMKM itu sendiri. Dari aktivitas yang telah dilakukan maka tim pelaksana merekomendasikan:

1. UMKM harus terus mengaktualisasikan dirinya agak mampu mengejar cepatnya perkembangan bisnis dan integerasinya dengan Teknologi Informasi.

2. Perguruan Tinggi harus secara berkesinambungan melakukan pendampingan dan pelatihan pada UMKM yang cenderung tradisional dalam tata kelolanya agar terus mengaktualkan tata kelola nya sehingga mampu berkembang dan bersaing secara nasional maupun internasional.

3. Tenaga pendidik dapat mengintegerasikan mata kuliah pengantar bisnis, pemasaran, dan kewirausahaan dengan aktivitas pemasaran online yang dibutuhkan UMKM. Pengintegerasian ini dapat dilakukan melalui project-based learning. Selanjutnya, tenaga pendidik dapat pula mendorong mahasiswa untuk mengikuti kegiatan PKM-Kewirausahaan dengan topic yang mampu mengisi kelemahan UMKM dalam branding dan pemasaran. Sehingga disamping mahasiswa belajar dengan program kreativitas mahasiswa, mereka juga dapat secara langsung berperan dalam pengembangan UMKM.

\section{Ucapan Terima Kasih}

Terima kasih disampaikan kepada LPM UNIMED yang telah mendanai keberlangsungan kegiatan pengabdian kepada masyarakat ini.

\section{Daftar Pustaka}

Indarti, Nurul (2010) The Effect of Knowledge Stickiness and Interaction on Absorptive Capacity: Evidence from furniture and software small- and medium-sized enterprises in
Indonesia. PhD Thesis. University of Groningen, Groningen, Belanda

Kementerian KUKM, \& BPS. (2004). Pengkajian Dukungan Finansial dan Non Finansial dalam Pengembangan Sentra Bisnis Usaha Kecil dan Menengah. Jakarta: Kementerian KUKM and BPS.

Handaru, Agung Wahyu; Widya Parimita; Inka Winarni Mufdhalifah (2015) Membangun Intensi Berwirausaha Melalui Adversity Quotient, Self Efficacy, dan Need For Achievement. JMK, VOL. 17, NO. 2, 155-166

Sulila, Ismet (2016) Pemberdayaan Masyarakat Melalui Peningkatan Kapasitas Manajemen dan Mutu Pada Kelompok Kerajinan Karowo di Desa Bongo Kabupaten Gorontalo. Jurnal Pengabdian Kepada Masyarakat Vol. 22. No. 3

Irawan, Yeni; Diana; dan Marlina (2016) Optimalisasi Produksi dan Pemasaran Aksesoris Jilbab Dari Kain Perca di Desa Tambon Baru Kabupaten Aceh Utara. Jurnal Pengabdian Kepada Masyarakat Vol. 22. No. 3

Afifah, dan Suryani, Yosi (2016) Serundeng Ubi Sebagai Salah Satu Peluang Usaha dalam Meningkatkan Pendapatan Keluarga; Studi Kasus Pada Usaha Marisa di Kota Padang. Jurnal Pengabdian Kepada Masyarakat Vol. 22. No. 3 